\title{
Magic between Europe and India: On Mantras, Coercion of Gods, and the Limits of Current Debates
}

\author{
Martin Fárek ${ }^{1, *}$ and Pavel Horák ${ }^{2}$ (D) \\ 1 Department of Geography, Faculty of Science, Humanities, and Education, Technical University of Liberec, \\ Komenského 314, Liberec 5, 46001 Liberec, Czech Republic \\ 2 Department of Critical Heritage Studies, Institute of Ethnology of the Czech Academy of Sciences, \\ Na Florenci 3, 11000 Prague, Czech Republic; horak@eu.cas.cz \\ * Correspondence: martin.farek@tul.cz
}

check for updates

Citation: Fárek, Martin, and Pavel Horák. 2021. Magic between Europe and India: On Mantras, Coercion of Gods, and the Limits of Current Debates. Religions 12: 87. https:// doi.org/10.3390/rel12020087

Received: 18 December 2020

Accepted: 21 January 2021

Published: 29 January 2021

Publisher's Note: MDPI stays neutral with regard to jurisdictional claims in published maps and institutional affiliations.

Copyright: (c) 2021 by the authors. Licensee MDPI, Basel, Switzerland. This article is an open access article distributed under the terms and conditions of the Creative Commons Attribution (CC BY) license (https:// creativecommons.org/licenses/by/ $4.0 /)$.

\begin{abstract}
Several scholars have criticized the efforts to explain Indian mantras as spells, but much is left to clarification. Why do submission-versus-coercion characterizations keep reoccurring, albeit disputed? Why does the difference between this-worldly and other-worldly goals also keep its important role in discussions about mantras? Furthermore, how are these ideas tied to analyses of the beliefs of practitioners? We identify three main positions concerning mantras: They are explained as spells, prayers, or both at the same time. However, the criteria for determining whether mantras are magical practices or religious practices apparently allow for characterizing the very same mantra as either of the two or even as 'magico-religious'. The general theories of magic are not able to explain this problem. In the last part of this article, we analyse the role that the concept of supernatural powers plays in the debates. It was a whole structure of interconnected ideas, deeply rooted in Christian belief in a biblical God and fallen angels, which formulated the dominant characterization of magical practices in modern scholarship on India. We propose a three-step scheme which shows how the originally coherent account of Christian theology gradually dissolved into a set of problematic ideas that have typified discussions of Indian mantras over the last six or more decades.
\end{abstract}

Keywords: magic; mantra; Indian religion; spell; prayer; coercion; Christian theology

\section{Introduction: How to Understand Mantras?}

There is a growing dissatisfaction with the explanation of Indian mantras as spells or charms, that is, as examples of magical practices (Gonda 1963a; Alper 1989; Staal 1996, p. 191; Burchett 2008; Cohen 2020). Yet a closer look at the development of scholarly ideas about the use of mantras reveals a strange picture: First of all, the debate is not new; in fact, early Orientalists had already suggested that mantras are prayers (and not spells, as some Christian missionaries claimed). Others, like John Woodroffe, believed that "there is nothing necessarily holy or prayerful about a mantra" (Avalon 1950, p. 83). Over the last 200 years, scholars kept wavering between the two positions: Mantras are prayers and therefore instances of religious practice; or mantras are spells and therefore examples of magical practices. Still others described mantras using both concepts, along with some other concepts (such as 'mystical utterance'), without coherence or proper explanation of their exact meaning. Although newer routes for research have been proposed (such as Staal 1996 or Yelle 2003), we argue that without proper analysis of the wider structure of ideas in the background and the criteria for distinguishing magical activities from other kinds of human activities, current research on mantras will remain trapped within the same cycle of problems, shaped by ideas about spells and prayers.

Among the most often noted characterizations of magical practices, one has maintained a special position: coercion or manipulation of supernatural powers (or beings). Although disputed, it remains one of the crucial characterizations, so much so that F. Graaf asked, "why, then, is it invested with such importance in European thinking about magic?" 
(Graf 1997, p. 227). Picking up this question, we strive to understand which ideas shaped the development of this characterization of magical practices, and how exactly they did so. Another important question is the emergence of a differentiation between 'this-worldly' and 'other-worldly' goals ascribed to the practice of mantras (Conze 1953; Goudriaan 1978; Padoux 1989). Why do these two characterizations keep their central position in analyses of this Indian practice, though contested and sometimes rejected?

We argue that, in the course of discussing criteria that would characterize mantras as magic, a deeper structure of theological beliefs of Christian origin comes to the surface. Although several scholars already pointed out this connection for analysis of the characteristics of magical practices (Thomas 1971, 1975; Tambiah 1990; Burchett 2008), it still has not been made clear what exactly is wrong with these characterizations being of theological origin. Recently, M. Keppens and J. De Roover showed more precisely how some ideas shaped by Christian demonology were transformed into modern theories about Brahmins' "magical powers" (Keppens and De Roover 2020). We will go further in this direction and strive to show that it was a whole structure of interconnected ideas, deeply rooted in Christian belief in a biblical God and fallen angels, which formulated the dominant characterization of magical practices in modern scholarship on India. We propose a threestep scheme which explains how the originally coherent account of Christian theology gradually dissolved into set of vague and otherwise problematic ideas that have typified discussions of Indian mantras over the last six or more decades. Only then we will be able to step outside of this framework of ideas.

\section{Are Indians Adoring Their Gods or Manipulating Them?}

In order to create a vivid picture of the current situation, we ask you to imagine the dilemma an eager student faces: interested in the use of mantras in India, let us say especially in the Tantric traditions, he or she took up religious studies or Indology. The student will accompany us in this and the next section. Diving into the waters of scholarship on mantras, our student would discover a discussion of whether mantras are prayers, spells, sacred formulas, or charms. Although "mantras are not readily classifiable as prayers or spells" (Alper 1989, p. 13), this is exactly what the majority of scholars kept doing for the last 200 years. While some influential scholars explained these phenomena as prayers or "holy words" (Colebrooke 1858; Wilson 1861; Deussen 1894), others insisted that they are spells or charms (Ward 1822; Ewing 1902; Charpentier 1932). And yet, others used the terms interchangeably, leading to an impression that magical and religious practices are ultimately the same thing (Gonda 1950, 1963a; more below). Let us see what our student can learn from these debates.

First, it is noteworthy that both basic explanations of mantras were present in 19th century European scholarship on India: for the early British Orientalists, mantras were prayers; for others, originally mainly missionaries, they were spells. In these early debates, a set of problems is visible, and it remains with us to this day, as we strive to show below. Second, the debate about whether mantras are spells or prayers is closely linked to the debate about the character of Vedic mantras, which crystallized into the notion of a division between $\mathrm{Rg}$, Sama, and Yajur Veda Samhitas on the one hand, and Atharvaveda Samhita on the other. The first three Samhitas were explained as religious, because they would have been prayers to gods, whereas Atharvaveda Samhita was considered magical because of its alleged spells. Yet even this division, although often used to this day, is hardly a consensus. Some modern scholars think all Vedic mantras are magical (see Jamison 1991 below). Third, with the emergence of Tantric studies, the mantras of traditions labelled Tantric were explained as spells or charms. However, either some Tantric mantras were attributed a 'Vedic origin', or characteristics typical of both Vedic and Tantric mantras were discussed, which makes the division between Vedic prayers and Tantric spells doubtful. In this section, we deal with these topics in connection with our central question about characterizations of prayers and spells. 
We suggest that a closer reading into these matters reveals that the criteria used to characterize mantra as prayer and the criteria used for mantra to be understood as spell were formed within the same theoretical framework. Let us start with H. T. Colebrooke, who wrote about mantras as prayers. In his view it was obviously so, because mantras are always directed to a deity: either it is a petition to a given deity, or thanksgiving to it, or adoration, or praise of the same (Colebrooke 1858, p. 9). In other words, it is a part of worshipping Indian gods. The word mantra was also translated as 'prayer' by H. H. Wilson in his Sketch of the Religious Sects of the Hindoos, and was used as such consistently throughout the book (Wilson 1861, see especially pp. 133, 176, 247, 318). It is noteworthy that the concept of spell does not occur in Wilson's book at all. F. M. Müller understood several concepts from Rig-Veda as prayer: first of all, the famous bráhman; but also dhiyá, and medhá. The last word, however, also means 'will' or 'thought', according to the famous scholar (Müller 1869, pp. 48-49, 66-47, 149, 153, 157, 158, 178, et al.). His rival at Oxford University, M. Monier-Williams, also described Vedic mantras as invocations, hymns, or prayers that should 'praise the gods' (Monier-Williams 1883, pp. 2, 8, 11, 19, 22). Paul Deussen understood Vedic mantras as prayers (Gebeten in the German original) because they should 'worship the deity' as their object (Deussen 1894, p. 47), and this is commonplace in more recent scholarship. According to this explanation, mantras are a form of adoring the gods of India.

However, the British Orientalists themselves quoted instances when mantras do not address any deity at all. Thus, for example, there are Vedic hymns addressed to kings and their wives (Colebrooke 1858, p. 11; see also Wilson 1861, pp. vi-vii); and we can quote 'prayers' offered by a groom to women while his bride is taking new pieces of cloth during a marriage ceremony:

May those generous women who spun and wound the thread, and who wove the warp and weft of this cloth, generously clothe thee to old age: long-lived woman! Put on this raiment. Clothe her; invest her with apparel; prolong her life to great age. Mayest thou live a hundred years. As long as thou livest, amiable woman! Revere beauty and wealth. (Colebrooke 1858, p. 134)

Such examples raise questions about the precise meaning of prayer here: In the last quoted instance, the request to 'generous women' can be understood as real, or perhaps symbolic. In any case, it is a request of a human being addressed to other human beings, not to gods; so why is it a prayer? An analogous problem appears when 'adoration' is used in reference to kings and their wives. Scholars also noted that even though mantras with names of deities were used during rituals, they were often broken into smaller units and woven according to certain patterns into longer sequences of words that hardly petition these deities. Finally, British Orientalists mentioned the existence of meaningless mantras, but did not know how to account for them. Such mantras simply cannot be explained as prayers under any of the characterizations mentioned above (praise, thanksgiving, etc.):

It is likewise to be observed, although mantras of the Védas are ordinarily significant, that the chants of the Sámavéda are unmeaning. They consist of a few syllables, as irá áyirá, or girá gáyirá, repeated again and again, as required by the tune or rhythm. (Colebrooke 1858, p. 197)

Leaving aside for a moment these problems of explaining mantras as prayers, our student turns to the second position: What would make mantra into an example of magical practice? The direct use of Christian ideas about pagan idolatry misleading worshippers and directing them towards the wrong goals in life is obvious here, both in the books of Christian missionaries and scholars. Thus mantras were described as 'formularies' by William Ward, one of the famous Serampore Baptists:

... the Hindoos ... some of their idols are actually personifications of vice; and the formularies used before the images, so far from conveying any moral sentiment, have the greatest possible tendency to corrupt the mind with love of riches and pleasure. (Ward 1822, p. 1xv) 
In the Orientalists' view, idolatry was the result of a degeneration of original Vedic monotheism. We already mentioned that Monier-Williams considered Vedic mantra to be prayer, because a mantra is "properly a divinely inspired Vedic text"; but it somehow lost its character and became "a mere spell or charm with the great mass of the Hindus in the present day" (Monier-Williams 1883, p. 197). Similarly, H. Oldenberg speculated about bráhman originally meaning 'holy word', which changed into 'magical word', and many other scholars accepted this view (see Gonda 1950, pp. 3-4). Our student is learning here about differentiating between a noble and pure religion of Vedas and that which degenerated into Brahmanism and, later still, into Hinduism, according to the influential Orientalists of the nineteenth century. They postulated a theory about the much later development of Shaktism and Tantrism, which were in their "left-handed, or indecent mode of worship" seen as "unbridled debauchery with wine and women" (Colebrooke 1858, pp. 124-25). The degeneration of mantra practices from Vedas to Tantras was expressed in the early studies as follows:

The Mantrin was determined to have his Mantras highly regarded and so he creates a theory according to which no power will be too great to attribute to them. Not that the idea originated with the Tantrics. Speech is a goddess of the Rig Veda and the power of brahman or the 'holy word' was recognized from earliest times. The Tantras are in this matter but a degenerate offspring of an honored parentage. The Brahmana with his brahman is the grandfather of the Mantrin with his Mantra. The one is sacerdotalism with a strong inclination to sorcery; the other is sacerdotalism immersed in an ocean of sorcery. (Ewing 1902, p. 70; emphasis ours)

Evaluating the goals pursued by worshippers became an important part of discerning between spells and prayers. If mantras are used for 'salvific' or other 'noble' causes, it is religious performance. If they are used for this-worldly, and especially 'selfish' or even 'harmful' goals, they are magical. Thus T. Goudriaan characterized, for example, desires for 'intercourse with supernatural women', that is, 'female demons', in the influential book Maya Divine and Human: A Study of Magic and its Religious Foundation in Sanskrit Texts (Goudriaan 1978, pp. 103-4). Therefore, discerning between this-worldly and otherworldly goals plays its role in efforts to understand mantras. Let us note carefully the implicit idea about the fundamental difference between these two kinds of goals in Tantric practices:

(Tantrism) recognizes and expounds mundane aims beside spiritual emancipation of final release as a lawful goal for a practiser. 'Realization' indeed implies both aims which are hardly separable in the texts. 'Domination' is an essential aspect of 'deification'. This again implies that Tantric methods are considered applicable for various sorts of practical attainments including astrology, medicine and magic. In practice, many written sources of Tantrism are pre-occupied with the description of supernatural abilities (siddhi-, 'attainments' or the magical satkarmani 'six acts'). There remains, however, always a connecting thread between the popular and the individual or esoterical; between the magical and the spiritual. (Goudriaan 1978, p. 7)

In Orientalist scholarship, we also find an acceptance of evolutionary theories of religion, which consider magic to be a necessary early stage in the development of humankind. ${ }^{1}$ This evolutionary model—from primitive magic to advanced religion-is characterized by a shift from this-worldly to other-worldly goals. The use of mantras, or in Buddhist case dháranís, was understood accordingly:

1 Both degeneration and evolutionary theories of religion are mentioned specifically as explanations of mantras in Hastings' Encyclopaedia of Religion and Ethics, where they are characterized either as 'spells' or 'prayers' (theories describe the change from prayers to spells or the other way round; see Hastings 1910, pp. 441-42). This is in the entry 'Charms and Amulets (Indian)'; use of 'spells' of Atharvaveda is described in a separate section 'Charms and Amulets (Vedic)' (Hastings 1910, pp. 468-72). 
At first the Buddhists, like all the other inhabitants of India at the time, expected from magical formulae protection from danger, and furtherance of their worldly interests. The use of spells for such purposes was widespread among all nations in the pre-industrial period of human history. It implied at least two assumptions, i.e., that diseases and many other misfortunes are due to the influence of some demonic power, and, that words have power to deal effectively with the demon, by either driving him out, or driving him away, or by mobilizing some greater benevolent magical power against him. (Conze 1953, p. 181)

Within the evolutionary model of moving from magic to religion, Conze explicitly identified two different goals, namely 'full enlightenment in this life' and 'success in gaining health, wealth and power' (Conze 1953, p. 176). It is noteworthy that this Tantric combination of this-worldly and other-worldly goals is characterized by Conze as 'illogical' (Conze 1953). He identified three stages of mantra use in Buddhist traditions. Mantras described as spells originally aimed at this-worldly goals; however, "from the seventh century onward" they "become, among a section of the community, the chief vehicle of salvation in the Mantra-yana, (The Vehicle of the Mantras)". If they are practiced properly, that is, according to established rules, "there is nothing they cannot achieve" (Conze 1953, p. 182).

Other researchers of the twentieth century also maintained that mantras can be described as spells, but focused on manipulation (sometimes 'coercion' is used) as their main characteristic. The idea comes also from earlier research, which pointed to the 'Hindu belief' that an able magician is superior to gods. In this connection Monier-Williams noted that "no magician or wizard" claimed to be able to accomplish "half of what the Mantra-sastri claims to have power to effect by help of his mantras" (Monier-Williams 1883, p. 201). This explanation saw a common source of magical practices for both Hinduism and Buddhism in the Brahmanas, traditionally connected with Vedic Samhitas:

As in the days of the Brahmanas, it was thought that these deities should be compelled rather than persuaded. The textbooks outlining the means (sadhana) of doing this were called Tantras, and hence the new cult is often referred to as tantric. By pronouncing the right formula (mantra) in the correct manner, or by drawing the correct magical symbol (yantra), one might force the gods to bestow magical power on the worshipper and lead him to the highest bliss. (Basham 2004, pp. 282-83; emphases ours)

We intentionally quote from the latest edition of Basham's classic The Wonder That Was India, because the book has been used in many classes on Hinduism and Buddhism for more than half a century by now, teaching about the coercion of gods by means of mantras. Yet it is not only god or the gods whom the magicians allegedly believed to manipulate; sometimes it was control of hidden forces of invisible reality. Compare these explanations of two more recent scholars:

As is well known, the Indians had, from the beginning, a strong inclination to reflect over the invisible and intangible reality behind the phenomena ... they tried to control these potencies ... the quest for knowledge of the mutual connections of all that has a name ... in their opinion, a potency A would doubtless be known and controlled, if only its identity with a potency B ... could be established. (Gonda 1950, pp. 8-9)

It hardly needs to be reiterated that in Vedic ritual in general the human microcosm is manipulated in order to produce results in the divine macrocosm through various types of sophisticated sympathetic magic, both physical and verbal. It seems reasonable to extend this principle to the mythological sphere by assuming that, to the Vedic mind, parallel experience between a human and a god would make that human especially qualified to act in the divine realm, to manipulate the god whose experience matches his own. The efficacy of sympathetic magic depends on homologies: only by exploiting such often mystical or cryptic similarities can 
man use his weak means to control forces far more powerful than his. (Jamison 1991, p. 243; emphasis ours)

The third position in the debate basically merges the two previous stances into one: it claims that the very same mantras could be prayers and spells at the same time. Our student would note a strange thing: the division between Vedic and Tantric mantras is disputed, but is usually retained on different grounds than the ideas about the alleged degeneration of the monotheistic worship of Vedas, quoted above (see Staal's criticism of Wheelock and others in Staal 1996, pp. 224-36). With this shift it is not clear why and how the Vedic mantras would also be spells. Those who use the term also keep speculating about the Vedic deity Vác (Speech), about brahman being prayer, and about sacred force attributed to mantras:

The sacramental force of a mantra is apparent from its use as an initiatory formula, for instance at the ceremony of receiving a new member in a religious order. Generally speaking the guru (religious teacher or spiritual mentor), initiates the adept into the mysteries of the sacred words. Mastery over spells (mantravidyá) came therefore to be considered as a creditable qualification of teachers and spiritual guides. (Gonda 1963a, p. 266)

Although Jan Gonda, in his still-influential article, did not finally take a clear position on the problem of differences between magical and religious uses of words, a strange ambivalence in the text is noteworthy. Gonda expressed dissatisfaction with all the different translations that had been used by his time for the concept of mantra and concluded that it is not possible to translate the Indian term into Western languages (Gonda 1963a, pp. 245-47). This can indicate that in the traditional Indian understanding, mantra is utterly different from prayer, spell, sacred formula, or other phenomena being discussed. However, Gonda did not follow this line of possible research further. He mostly described different instances of mantras (from Vedic rituals, from Tantric rituals, from diverse bhakti traditions, etc.) and mentioned the goals these practices could help to achieve. Finally, he claimed that "a mantra is not a prayer", which is quite surprising in the light of his arguments on the previous pages and of the statement which immediately follows: "This is, however, not to contend that there are no mantras which may be used as prayers, or which are prayers from no point of view" (Gonda 1963a, p. 284). What led Gonda to conclusions such as these is left opaque.

However, with the possibility that mantra is something altogether different from prayers or spells, there is another insight our student can take from the article: Gonda started his debate as a reaction to 12 categories of "manifestations of the sacred word", formulated in Erscheinungsformen und Wesen der Religion, the theological classic of F. Heiler (Gonda 1963a, pp. 244-45, 252-53). Despite explicit remarks by the famous Indologist that all of the theological explanations given by Heiler cannot be applied to mantras, somehow Gonda also accepted them and concluded that mantras "were mainly used in magico-religious rites, for the purpose of furtherance of worldly interests and protection from danger" (Gonda 1963a, p. 295). Gonda's claim is puzzling, because this part of article basically follows ideas of evolutionary theory (from magic to religion). Why does the criterion of pursuing this-worldly goals not let the author clearly decide that these mantras were at first used only in magical rites? Why are they 'magico-religious', despite the talk of different goals? This formulation became commonplace, as entries in encyclopedias and indexes of influential books show. ${ }^{2}$

What has our student learned at this stage? About the existence of several problems: (a) one characteristic of magical practices should be manipulation (or coercion), but the explanation of who or what is believed to be manipulated differs among scholars; (b) typically, certain kinds of goals that mantra practices attain, according to the beliefs

2 According to more recent sources, mantras are used "in prayer, meditation, or worship" (Eliade and Adams 1987, p. 66); they are described as "verses or phrases believed to have magical or religious efficacy" in the 10th edition of Basham's Cultural History of India (Basham 1996, p. 556) or as 'magico-religious speech' (Zysk in Alper 1989, pp. 123-43). 
of the practitioners, are described according to divisions between this-worldly and otherworldly goals. Although disputed, several generations of scholars keep using the pursuit of this-worldly goals as characteristic of magical practices; (c) these criteria for determining whether mantras are magical practices or religious practices apparently allow for characterizing the very same mantra as either of the two, or even as 'magico-religious'; (d) some mantras do not fit the characteristics at all, but they are also explained as spells, prayers, or both at the same time; (e) ideas about the degeneration of the original monotheism or evolution from magic to religion were theoretical frameworks of the efforts to understand mantras. Therefore, ideas about gods, demons, or supernatural powers play some role in the debates, but it is not clear what exactly is discussed. Is it an attitude of worshippers towards these beings? For example, Vedic gods are adored and prayed to according to the early Orientalists, whereas some scholars of the later generations maintain that the very same mantras are used as a means of manipulation of the same gods. Would general theories of magic help our student to solve these problems with understanding mantras?

\section{Intermezzo: Does Magic Exist?}

We suggest that turning to general theories of magical practices will yield some important insights, although our student is destined to discover notorious problems that will make the situation worse for some time. Why? Because the scholarly field of magic appears to have fallen on hard times. Where the founding fathers of comparative religion, sociology, and anthropology once formulated bold ideas and grand theories, many scholars today are skeptical about the possibility of solving the basic problems that research in magic brought forward.

Our student will learn that, for many scholars, magic exists as a universally shared kind of human activity, ranging from the prehistoric magic of hunters (sometimes described as shamanism), through various ancient traditions, early modern Hermeticism, the magic of Asian, African, Native American, and other peoples, to different modern schools of magic. ${ }^{3}$ In this perspective, the concept of magic with its characteristic features provides a useful description of all these activities, including mantras. However, other scholars insist that it is not possible to use any universal concept for understanding such a range of phenomena. Instead, they propose to define magic for different cultures and periods differently. A recent text summarizes the position well:

Since then [the times of Edward Tylor and James Frazer, M.F. and P. H.] much ink flowed in the river of scholarship, and the propositions of the two were altered, making room for new theories. These, however, often leave the reader with the frustrating feeling that the question of definitions remains open. It is now clear that 'magic' in the context of a pre-industrial African tribe (a term that replaced Taylor's 'savages') does not have the same meaning as it does in a Graeco-Roman context. It seems that the attempt to establish universal definitions proved unsuccessful, and the present approach is to examine the term independently for each culture and period. (Saar 2017, p. 6; see also Otto 2013, pp. 339-41 and Collins 2008, p. 2)

Yet what exactly does one make of the phrase 'to examine the term independently for each culture and period'? If some activities of 'a pre-industrial African tribe' described as magic require a different definition of the word from the one describing activities of the 'Graeco-Roman context', are scholars studying the same phenomenon in these cases, or not? For our student, the inquiry is about Indian mantras, but the question remains. If

3 Range of works holding this position is vast, and if one scholarly volume should be considered as starting the new chapter in research of magic, it is a work of Thorndike (1923). Primitive cultures were discussed in seminal works of Lévy-Bruhl (1926) and Malinowski (1935). General overviews span from introductory books (Cavendish 1987) to specialized volumes (Behringer 2004). Some scholars specialized on periods in the long history of magic, such as the Early modern period overview written by Alt et al. (2015), Butler (2011) in terms of magic in Victorian Britain, and Strube (2016) in the French context. More up-to-date examples include studies into modern left-hand path magic (Granholm 2014) or modern Paganism (Luhrmann 1989). A comprehensive historical survey of magic from antiquity to nowadays was provided by Otto (2011), for discussion of modern and contemporary movements see, e.g., Bogdan (2012). 
incantations of the ancient world and Indian mantras are phenomena of the same kind, what is the problem with using the same word in reference to them? And if they are not the same kind of phenomena, why should one and the same the word be redefined in order to describe them? Why do we not use some other word to indicate that we are dealing with different phenomena in the world?

Possibly a larger dose of frustration will come to our student with the discovery of an even more puzzling idea: Some scholars have suggested that magic does not exist at all. If the student learned about the magical use of mantras in some introductory course on Hinduism (see materials used often as textbooks, such as Flood 1998, pp. 101-2, 155, 160; or Michaels 2004, pp. 26, 228-29) and Buddhism (Harvey 1990, p. 134; Williams and Tribe 2000, pp. 206-8), a consultation of specialized books and journal articles will cause this surprise. To cite one example in the study of Indian mantras that is typical of such claims for the non-existence of magic:

Some authors (e.g., Smith 1989, p. 36) object against the use of the word magic, claiming that this term indicates utter foreignness and difference of the activities concerned, that it distinguishes them from proper religion, that it emphasizes their problematic nature, etc. None of this is here intended. No claim is here made that there is such a thing as magic, or that the term has been, or can be meaningfully used. (Bronkhorst 2001, p. 176; emphasis ours)

And yet, Bronkhorst went on to speculate on the nature of what has been discussed as the characteristics of magical thinking, trying to tie it to his understanding of ancient Indian and Greek etymological thought. Apparently, authors of such claims nevertheless continued to use 'magic' and 'magical', either explicitly or implicitly. Knowing that magic has been an important topic in studies of antiquity, suppose our student turns for clarification to a friend who just defended a PhD in classical studies. Perhaps scholars in this field formulated more helpful ideas about magical practices?

Yet, here as well, modern research into magic seems to be as dissatisfying as the same topic in the study of India. Bernd-Christian Otto warned classical studies circles about the "dubious conceptual grounds" and "implicit assumptions or inherent understandings of the concept of magic" that dominate the discourse of the discipline (Otto 2013, p. 340). Our student would note that research into understanding mantras of India as magical, outlined above, showed the same kinds of problems as the study of magical formulas of the ancient world. The student's predicament could be accurately described by the following words of the classical scholar, if you substitute 'India' in place of 'classical antiquity' and 'Indian sources' for 'ancient sources':

To sum up: pervasive modern discussions about the concept of 'magic' in the study of classical antiquity as they are, they yet failed to establish a thorough theoretical and methodological perspective as far as their central concept is concerned. The majority of studies continue to perceive 'magic' as an adequate category capable of classifying ancient sources. Nowadays, definitions are usually rejected; terminological alternatives - to counteract the conceptual vacuumhave rarely been proposed. (Otto 2013, p. 315)

The same puzzling conclusion about the non-existence of magic would come to our student from statements by respected scholars in the field:

Magic does not exist, nor does religion. What do exist are our definitions of these concepts. (Versnel 1991, p. 177)

... magic, as a definable and consistent category of human experience, simply does not exist. (Gager 1992, p. 24)

Would anthropology have some solutions for this situation? In some lectures the student will hear about the classic works of Bronislaw Malinowski and other proponents of a general theory of magic, as different from religion. However, possibly in 
the very same anthropology course, our student will learn that "today, most anthropologists consider magic to be a part of religion, because it is associated with supernatural powers" (Stein and Stein 2011, p. 136). This is quite strange in light of the fact that earlier respected scholars in the field rejected the usefulness of the term magic altogether (Radcliffe-Brown 1952; Pettersson 1957; Evans-Pritchard 1965). Our student now certainly feels compelled to join fellow scholars' lamentations about the conceptual mess in studies of magic; but what is to be done? If the student is still eager to understand the use of mantras in Tantric schools of India, and he or she is not giving up the topic (or leaving the study program altogether, in a worse scenario), what routes remain open for interesting research into the matter? Of course, numerous publications offer detailed descriptions of ritual use of mantras, historical developments of the same, translations of treatises, commentaries, etc. However, after closer inspection, they suffer from the same kind of conceptual problems outlined above.

Let us suppose that our student overcame these frustrations and soon decided about at least one problem. Debates about definitions of words aside, the phenomena of practicing mantras are real. They exist, or existed in Vedic, Buddhist, Tantric, Bhakti, and other traditions of India. In different forms, they have become part of the global world we live in. We will not advance in understanding any phenomenon described as magic by merely arguing about the proper definition of the word. This is an important step, because research should aim at explanations of real phenomena. ${ }^{4}$

We also suggest that, as another gain from sifting through contradictory ideas, our student would be able to pick up confirmation of a conclusion from earlier research into the (alleged) magical properties of mantra. The characteristics of magical practices, as a set of more or less clear criteria, were seen as the opposite of the characteristics of religious practices. Scholars in different study fields dispute the very same set of characteristics for discerning between magical and religious practices. To use an example from the discussion of love spells in Hellenistic magic:

The magician also tries to produce miracles with his magic, but here the difference is fundamentally one of tone and sentiment. When one prays to a god, one asks for something which depends on his will and which can be graciously conceded; when a magic rite is performed, one demands of the power invoked that it acts in a certain manner. Religion, moreover, is much more than the act of prayer and supplication, since it touches on all the fundamental aspects of human life; magic, in contrast, deals with specific issues and tries to satisfy the magician's, or his client's, specific desires. A peculiar egoism, which manifests itself clearly in the request made, is characteristic of magic spells. (Teijeiro 1993, pp. 124-25)

Let us part with our eager student here. Bearing in mind the insights he or she learned, in the next section, we will focus on finding out why these characteristics our hypothetical student encountered seem to create problems in understanding the phenomenon in question.

\section{Coercion and This-Worldly Goals of Life: What is wrong with These Characterizations?}

Scholars struggled with the following problem: although magical and religious practices have been explained as being different from each other, the framework of ideas about them allowed for the very same mantras to be characterized as magical at times, religious on other occasions, and sometimes magical and religious together. Although there is a clear-cut set of characteristics that should help with understanding these practices, it seems

4 Our student could be encouraged by the work of several scholars to make this decision. In India studies, it would be S. N. Balagangadhara's examination of problems with diverse phenomena described as religion (Balagangadhara 1994); in classical studies, Marvin Mayer suggested that scholars had spent a lot of time trying to 'repair' their definitions of magic but had failed to make any progress towards explaining phenomena that are described by the term (see Johnston 2003, p. 50). Earlier, Skorupski remarked that 'it is a mistake to think that a theory of magic, or of religion, must begin with the definition' (Skorupski 1976, pp. 154-55). 
to only add to problems already mentioned. Academic ambiguity on this issue suggests that behind these problems, there is a deeper conviction that can be formulated as follows: magical and religious practices are fundamentally different from each other, yet they are also of the same kind. That is, although religion and magic are different from each other, they are also extremely similar. Is there a good explanation for such a claim? And can we connect this explanation with analysis of the ideas that created criteria for discerning between spell and prayer?

We think it is possible to build such an explanation. In fact, several scholars have already pointed in this direction for understanding the problems at hand. The possibility lies in a discussion of the role that Christian theological ideas play in modern attempts to explain magic. From the older texts, perhaps the most quoted to this day is "The Notion of Magic" by Murray and Rosalie Wax. Regarding magical practices, they remarked:

A concept with a definite meaning ... illuminates ... a significant concern of Western peoples. For example, the supplication/manipulation dichotomy does not apply to non-Western peoples, but it does reveal a great deal about how Westerners conceptualize their religion and their morality. (Wax and Wax 1963, pp. 502-3)

What exactly the dichotomy reveals was not properly discussed by the Waxes, nor by those scholars who directly reacted to their article (Wax and Wax 1963). Looking through the succeeding academic discussions, one finds much more about how the dichotomy does not apply to non-Western peoples than explanations of what exactly it reveals about Western conceptualizations of religion and morality. In his recent analysis of the alleged magical characteristics of mantra, P.E. Burchett repeated the claims of K. Thomas and S. Tambiah about the Protestant origin of ideas that would shape scholarly debates to this day. Using ideas from the debate between H. Geertz and K. Thomas, which followed the influential book of the latter, Religion and the Decline of Magic (Thomas 1971), and from the work of S. Tambiah (Tambiah 1968, 1990), Burchett concluded that Western problems with understanding mantras are the legacy of a Protestant division between religion and magic, which was somehow transformed in the thinking of the Enlightenment (Burchett 2008, pp. 829-34). This would cause the problems in modern theories:

Mantras certainly seem to have been placed in this category of 'downgraded alternatives' to modern Western views of language and religion. Conceived as 'spells' and 'magical formulas', as they are so often translated, mantras are by implication irrational attempts to manipulate the Divine, in contrast to the supplicative prayers of authentic 'religion'. (Burchett 2008, p. 831)

Yet one is searching this article in vain for an exact explanation of which Protestant ideas created the dividing characteristics between prayer and spell, and how they did so. When K. Thomas discussed how Protestants criticized Catholics for introducing magic to the Church, he meant that medieval Catholicism 'credited their rituals with physical efficacy' in the view of Protestants (Thomas 1975, p. 97). In response to H. Geertz, he described his historically limited concern as follows:

I explained how churchmen of every denomination used the term to brand as implicitly diabolical all unauthorized attempts to manipulate the supernatural, including many folk practices previously regarded by their adherents as godly (pp. 192, 256, 265-67); and how Protestants applied the same description to cover any claims to manipulation made by the Church itself. The dividing line between 'magic' and 'religion' was hardened by the parallel attempts of Protestant and Catholic Reformers to eliminate all popular rites of unauthorized and ambiguous status. (Thomas 1975)

If both Protestants and Catholics attempted the same goal (eliminating magical practices), they must have shared some basic understanding about these 'diabolical attempts to manipulate the supernatural'. What was this common ground? This question remains unan- 
swered after searching the works of Thomas and Tambiah. ${ }^{5}$ If the Christian characterization of a division between magic and religion became part of later Enlightenment rationalist thought, why exactly is it problematic? Answers to these questions are not self-evident. Let us start with a brief comment on the second question: Some important insights in science emerged because this or that particular Christian theological idea inspired criticism of the then-accepted view and, finally, led to an important shift. The emergence of a mechanistic worldview in the seventeenth century, which was the metaphysical basis for the research of Pascal, Boyle and Newton, is one such example (see Hooykaas 1972, pp. 7-26). However, their theories, originally formulated on the basis of Christian theological ideas, are testable, and their validity does not depend on assumptions about a biblical God and the creation of the world. With this understanding, we can go back to the first question about the allegedly Protestant origin of characterizations of magical practices in modern theorizing. We should carefully consider which Christian theological ideas shaped modern debates on magic, and whether the emerging characterizations (such as setting coercion versus supplication as a criterion) are still dependent on the original biblical assumptions, or not. Only then would we be able to clarify problems in the debate and move further with our understanding of mantras (or other practices described as magical).

Such a precise analysis of the ideas that enabled characterizing practices in India as magical was outlined in a recent article written by M. Keppens and J. De Roover. The authors showed how the Early Church Fathers' understanding of magic as human 'trafficking with demons', which should have been an important part of 'heathen idolatry', became a crucial structure of later European explanations of Brahmins as pagan priests and of their powers. For our discussion about mantras, this point is important, because it is this account's conceptual structure that "establishes a connection between the 'rites' and 'formulas' of pagan priests, on the one hand, and the occurrence of certain effects in the world, on the other" (Keppens and De Roover 2020, p. 11). Originally, it was simply believed that those who use mantras in India are using spells comparable to spells of the ancient world, and that they are effective because of the power of the demons who are subdued by these spells. However, as modern European theorizing on magic crystallized in the 19th and early 20th centuries, the explanation of causal forces in magical activities changed:

Instead of the practice of trafficking with demons, a distinctive mode of thinking now allegedly characterized the mental world of 'primitive (pagan) men'. That is, the invisible spirits no longer counted as a genuine connection between rites and spells, on the one hand, and events and objects in the world, on the other. Rather, pre-modern humans lived under the delusion that such causal forces operate in the world because of their magical and pre-scientific thinking. (Tylor 1871; Frazer 1922)

We will go further in this direction, because in order to understand how the characterization of magic under discussion emerged and what exactly is problematic about it, we have to examine the scholarly belief in magicians' belief, so to speak. If Keppens and De Roover are right, the original Christian structure of ideas about demons would still be present in the academic debates, in the form of a conviction of modern scholars that such ideas form the content of the beliefs of mantra practitioners. Let us see if this is the case.

\subsection{The Supernatural in Debates about Magic: God, Gods, and Demons}

Why do submission-versus-coercion characterizations keep reoccurring in scholarly debates, albeit disputed? Why does difference between this-worldly and other-worldly goals, as another dimension of difference between magical and religious practices, also keep its important role in discussions about mantras? And how are these ideas tied to analyses of the beliefs of practitioners? We argue that the missing link, which is needed

5 The two authors offer only brief remarks, such as the one about 'Protestant legacy harking back to monotheistic ideas of early Judaism' (Tambiah 1990, p. 19). 
to clarify all three questions, is an analysis of the role that the concept of supernatural powers (or beings) plays in the debates. It can be shown that these ideas were originally held together by the central concept of a biblical God and fallen angels, and that, with the gradual rejection of the concept, explanations of the characteristics of magical practices, as opposed to religious practices, lost their original coherence and clarity. We propose that this process happened in three stages, which we will describe further below (in Section 4.2). However, we also point out how the debates retained the concept of supernatural power in their focus on constructing the belief system of those who practice mantras.

When Keith Thomas pointed out that Protestant reformers stressed the dividing line between true religion and magic (false religion), and that Catholics joined them, he was basically right. However, greater precision is needed in this explanation, because Luther, Melanchton, Calvin, and many others built on ideas developed by the Church Fathers, from Justin Martyr to Augustine. This is not merely a general historical remark, because in the works of the Early Church Fathers we should look for ideas which enabled the distinction between true and false religion and consider how exactly this division is related to our concerns with prayers and spells. This division had several practical consequences for both branches of Western Christianity. For example, both Catholics and Protestants were concerned with what looked like widespread possession of people by demons, understood along the lines of the Church Fathers' explanation (see Levack 2013, an in-depth study of Christian demonology in modern Europe). Obviously, we can only briefly highlight several points that are relevant to our topic of characterizations of spell and prayer, leaving a number of other important ideas aside. ${ }^{6}$

For Christians in the first centuries of Church, the world was filled with demons that seduced those of fragile faith to the wrong path. Demons were held responsible for the appearance of hosts of false prophets and the creation of heresies (Justin Martyr and Irenaeus 1913, pp. 181, 334, 340-50; Tertullianus and Felix 1998, pp. 103-17; Hippolytus 1868 , pp. 107-8, 196-97, 300-1); for the creation of pagan stories about sons of gods, which were made up in order to divert people from the only true Son of God (Justin Martyr and Irenaeus 1913, pp. 189-90); for teaching people magic or astrology (Tertullianus 1987, p. 35; Athanasius 1971, p. 161); and, finally, for mental and physical diseases. In sum, demons were held responsible not only for human physical suffering but, more importantly, for spoiling human minds and souls: "What is daintier food to the spirit of evil, than turning men's minds away from the true God by the illusions of a false divination?" (Tertullianus 1869, p. 97).

In this perspective of Church Fathers, spells were functional means of 'trafficking with demons'. In fact, some of these Christian thinkers considered diverse ancient practices described as spells to originally have been the 'mysterious divine science' of the Jews which was related to the Creator of the universe. Thus, Origen argued against Aristotle and Epicurus that this science is a coherent system, dealing with titles of angels and demons and known to different nations (Origen and Chadwick 1980, pp. 23-24). Therefore, according to God's will, spells do bring results in the world. Origen did not forget to contrast them with the use of the name of God, and proper prayers in general (see the whole debate Origen and Origen and Chadwick 1980, pp. 23-26). In this way, conceptualization of the differences between prayers and spells reflects differences between true and false religion.

Worship of one true God, that is, the supernatural being described in the Bible, was true religion, whereas worship of beings or objects of this world was false religion (Rom 1:23-25; Lactantius 1871, pp. 4, 282-84; Tertullianus 1987, p. 35; Justin Martyr and Irenaeus

\footnotetext{
6 Whereas the distinction between biblical God and His fallen servants is crucial for differentiating between (true) religion and magic (that is, false religion), there is good evidence the ancients did not make such distinctions between their gods and demons (Lloyd 1979; Martin 2010). However, it is not important for our concerns here, as well as many other related topics: that Church Fathers disputed the nature of demons (whether they are fallen angels or their progeny (Reed 2005; Bradnick 2017, pp. 18-53)), the extent to which demons lost their power after the coming of Christ, etc. Nor is our goal here to summarize debates about how exactly Christian thought appropriated Jewish ideas of magical practices (Smith 1996; Klutz 2003), or to check recent objections to the dominant picture of the ancient world as full of magical practices (Meggitt 2013). These debates, in other contexts very important and interesting, would easily divert attention from the crucial subject we are discussing here: the structure of ideas that shaped characterizations of prayers and spells.
} 
1913, p. 165; Epistle to Diognetus in Lake 1917, pp. 353-55; Marcus Minucius Felix in Tertullianus and Felix 1998, p. 397). Christian ideas of God the Almighty, Perfect, Creator of the world, etc., were contrasted with pagan stories about gods and demons. Practices connected with the latter were amply criticized by Church Fathers. ${ }^{7}$ According to them, the biblical God does not need material sacrifices in the way that the pagan gods do, because $\mathrm{He}$ is Creator of the world. Human beings should forget about such ridiculous practices and worship their Creator through a moral life, following His precepts (Justin Martyr and Irenaeus 1913, pp. 165-66; Justin Martyr and Athenagoras 1909, pp. 388-90; Tatian and Theophilus 1871, pp. 8-9; Tertullianus and Felix 1998, pp. 67-9, 151-53; Tertullianus 1903, p. 122). If they desire something for their earthly life, within the limits of God's commandments, they should ask Him, which is one form of prayer. Other forms of prayer are adoration of God the Almighty, thanksgiving, confession of faith, etc. (Heiler 1979).

These ideas created a coherent explanation in which prayers are a means of contact between believers and a biblical God, whereas spells are a means of human communication with demons. The differences ascribed to these beings (God versus his fallen angels, or their progeny) imply differences in the approaches of the worshippers: a submissive approach toward a biblical God versus a coercive approach to demons. The biblical God cannot be coerced; this is simply a ridiculous idea for Christian theology. Human beings can properly pray to Him for both the final salvation of their souls and their 'daily bread' of this world. To think that coercion of demons, which works for the fulfilment of some desires, would be effective in forcing God the Almighty amounts to a revolt against the Creator. Understandably, such attitudes are ascribed to 'magicians' to this day in Catholic theology. The former Dean of the Theological Faculty at the Pontifical Lateran University in Rome described how a conviction that human claims or acts could "force God to realize salvation according to a human wish" amounts to nothing less than "the top of titanic pride" (Boublík 2000, p. 222). The author of these claims clearly continued the line of the Church Fathers' ideas about revolts against God, of which magic should be the best example, because it "reduces the deity of a higher and secret power to an instrument of certain people, magicians, according to their whims" (Boublík 2000). Such claims are shared by theologians of different denominations, being the heritage of the formative period of Christianity. ${ }^{8}$

What about the division between the different goals towards which prayer or spell should aim? Is it really necessary to point out the Christian theological character of the ideas that differentiate between salvation linked to a transcendent God after death and the temporary goals of life in our world? Of course, this is not an absolutely clear-cut method for discerning between prayer and spell, because prayers asking for 'daily bread' could and should be addressed to God. Therefore, this criterion must be compounded by the submissive approach of the worshipper. It is also clear that, although some people might think their spells will bring them salvation, in the theological perspective this amounts to the 'titanic pride' of somebody who aspires to control God Himself. In this perspective, spells do fulfil some temporary wishes, but finally, all magic seduces people from the right path to God and leads to damnation.

Now we see how exactly ideas about the nature of a biblical God, as a superhuman being who is different from all demons (or false gods), are a crucial background structure for the specific debates about magic being part of false religion. In the Christian theological perspective, religion means a special tie, originally with the Creator, or with those fallen creatures who dared to claim the position of the Creator. It is the most important relationship human beings have, but in the case of false religion, the second party is replaced by the wrong beings. In this sense, it is answering a question about how (true) religion can

7 A well-known instance is 1 Cor 10:20, where Paul declared that whatever pagans sacrificed to their idols, they sacrificed it to demons, not to God. Augustine stressed that "all the arrangements made by men for the making and worshipping of idols are superstitious, pertaining as they do either to the worship of what is created or of some part of it as God" (Augustine 1892, p. 56).

8 The characterization of magic in The New International Dictionary of the Bible is a good example (Douglas and Tenney 1987, p. 613). 
be the same and yet different from magic (false religion). Without these ideas, all discussions about a submissive versus a coercive approach by worshippers, this-worldly and other-worldly goals, and, by logical extension, also distinctions between spell and prayer, lose their precise meaning. These theological ideas shaped many centuries of European thinking about prayers and spells. As such, they became the conceptual source for those who began to study Indian traditions in the 18th and 19th centuries.

\subsection{From Clear Theological Explanation to Current Conceptual Mess}

We propose that the structure of Christian ideas about God and demons formed the core of the explanation of mantras as either prayers or spells. As modern scholars gradually rejected the explicit beliefs of their Christian heritage, those ideas lost their clarity or changed meaning; the relationships between them became loose or obscured, and the whole structure gradually dissolved. However, individual concepts, or sometimes two or three of them clustered together, remained. The first historical stage of research on the religions of India kept the originally Christian idea about the degeneration of the pristine monotheism of nations as a guiding explanation. The consequence for understanding mantras was simple: original Vedic teaching was 'monotheism', albeit with 'the seeds of idolatry' (see below), whereas Tantras were an 'ocean of sorcery'.

In this view, a pantheon of strange gods and demons usurped the place of striving for one true God, and thus there was a fertile field to dig in and write about Indian, Sinhalese, and other Asian 'demon worship' or 'witchcraft' (Upham 1829; de Silva Goonaratne 1865; Lyall 1899, pp. 99-130; Hildburgh 1908). Let us also remind ourselves of the fact that, for scholars holding this view, both prayers and spells do bring some effects in the world, although for different reasons. In the 19th century descriptions we can see these assumptions: If the scholar was convinced that Indian practitioners of mantras were basically monotheists, their worship of Vedic and other gods was in fact indirect worship of the one true God. These people showed reverence, and so their recitations must have been prayers that were 'adoring', 'petitioning', etc. It is unimaginable that, with this attitude, such believers would try to coerce the supernatural power they addressed. In the works of early Orientalists, we find appreciation of Vedic ritual, because their 'solemn rituals' did not use images or temples, and because such worship should have been recognition of God the Creator in the wonders of His creation. Thus, Colebrooke concluded that:

If the doctrines of the Véda, and even those of the Puránas, be closely examined, the Hindu theology will be found consistent with monotheism, though it contains the seeds of polytheism and idolatry. (Colebrooke 1858, p. 123)

If the scholar was convinced, as many Christian missionaries were, that Indians were simply idolaters, then all mantras were easily understood as spells. Did not the 'murmuring' of mantras resemble what was known about magical practices from ancient times onwards? Did not Indians use them for goals that looked exactly like goals of European magic? Healing but also harming others, igniting feelings of love in the heart of a chosen person, protection from all kinds of disasters, wealth, success in political endeavors, etc.; all these goals promised in Indian texts look very much the same as the promises of ancient magical texts. The list of goals "typical for magic" became a necessary part of accounts on mantra, with little changes over the last 200 years. It is usually accompanied by the explicit or implicit comments about this-worldly and soteriological goals (compare Dubois 1906, pp. 138-43; Monier-Williams 1883, pp. 197-203; Gonda 1963a, pp. 265-67; Burchett 2008, pp. 816-17).

The second stage of changes in the structure of explanatory ideas was formed by the rise of grand theories of magic, formulated by Tylor, Mauss, Frazer, or Durkheim. These theories understood magic as an early stage of development of religion, being in this sense a reverse of the degeneration model. These two explanations sometimes stand together as alternatives for understanding mantras (from prayer to spell or the other way round). The explicit ideas about a biblical God and demons or their progeny were slowly fading into the background of research at this stage, together with the beliefs of scholars in the efficacy 
of either religious or magical practices. ${ }^{9}$ However, they are still traceable in these accounts, transformed in the search for the character of the supernatural beings that believers in magic would have imagined. ${ }^{10}$ Sometimes the concept of these beings seemed elusive, and as a consequence, it seemed difficult to explain magic as such:

The vague, multiform character of the spirit powers with which magicians have to deal is also a feature of magic as a whole. At first sight, the facts we have collected together may seem very disparate. Some tend to merge magic with technology and science, while others assimilate it to religion. In fact, it should be placed somewhere between the two, but it cannot be defined by its aims, processes, or its ideas. Up to the present, our studies have shown that the subject is even more ambiguous, more indeterminate than ever. (Mauss [1902] 2001, p. 106)

However 'vague' the character the 'spirit powers' of Indian magicians might be, it was still important to compare this character with the character of a perfect deity, as in the once influential work of Stanislav Schayer, Die Struktur der magischen Weltanschauung nach dem Atharva-veda und den Brahmana-Texten (The Structure of the Magical Worldview according to Atharva Veda and the Texts of the Brahmanas). ${ }^{11}$ Schayer's understanding of magic was based on its assumed difference from religion, which for him had to do with the concept of God. He claimed that religious beliefs postulate the existence of God as an absolute individual, with his own will, and that God's will is expressed in all his acts. Magical thinking, however, created only concepts of 'binding powers', which are 'substances', or a kind of 'pseudo-individuals', who are prone to manipulation and the rule of an able magician (Schayer 1925, p. 6). The coercion of demons, which was seen as functional in the original Christian account of magic and kept its salient role in the earlier scholarly works on mantras, thus became part of the alleged beliefs of practitioners, as Keppens and De Roover suggested. In Schayer's explanation, the originally Christian concern with the personal qualities of a biblical God is retained, but demons are not personalities any more. Nevertheless, the difference between religious worship and magical ritual is still clearly based on the original Christian ideas, including the idea about both involving a tie with 'the supernatural powers':

Magic shares with religion the following characteristic: it assumes the consciousness of a link with the supernatural powers. However, the spiritual stance of magic is fundamentally different from that of religion. Because while the religious man strives hard to uplift himself through the dependence upon the sovereign God's Will, in personal and emotional contact, the Magical man knows only an abstract, impersonal tie established through a magical rule, that he strives to find out and to make a servant of his goals. In this way, the cult becomes a mechanical technique, and every act through which the tie would be lost, an exemplary failure of the general rule. (Schayer 1925, p. 6)

Schayer also maintained the general theory of the degeneration of religion into magic, of which "the development of Indian religion from the hymns of Rg Veda to Brahmanas" should be "the classical example" (Schayer 1925, p. 7). His explanation of mantras is a logical outcome of this theorizing: the pious prayers of the Rg Veda, by which believers only hoped to attract the grace of gods, are contrasted with "ecstatic and emotional magic", "shamanic demonology", and "sexual orgies" of the Atharva Veda (Schayer 1925, pp. 7-12). It is interesting to see how Schayer combined ideas about "the fall of Vedic theism" with current speculations about the primitive mindset of ancient people. He connected older

9 This tendency typically took the form of distancing the personal beliefs of the scholar from the explanations he pursued in research, but this 'professional distance', or 'bracketing', of personal beliefs did not guarantee that the structures of Christian ideas would not shape their theorizing as such.

10 See also today almost forgotten work of Jevons, who speculated about beliefs of primitive people in "supernatural spirits". According to this author, primitive man thought he could "constrain the gods to work his will" by means of magical practices (Jevons 1896, pp. 15-34).

11 All quotes from Schayer's work are M.F's translations from the original German text. 
speculations about primitive man not being able to discriminate between abstract ideas and real phenomena in the world with newer speculations about "symbolic equivalence" from the pen of L. Lévy-Bruhl (Schayer 1925, pp. 13-19). Such ideas postulated the content of magical beliefs, according to which primitive people allegedly saw the unity and interconnectedness of words and phenomena in the world, and also connections between microcosmos and macrocosmos. Schayer used examples from the Upanishads to illustrate how primitive people believed in the fundamental identity of wind and breath, sun and eye, or herbs and hair (Schayer 1925, p. 31). This worldview should have created a belief in the power of words in the mind of primitive man: one who knows hidden connections between words and phenomena can control the latter by proper use of the former. Theorizing of this kind was commonplace in psychology, anthropology, religious studies, and other disciplines of the period between the World Wars. ${ }^{12}$ However, independent of the theological ideas such theorizing may look, it retains the Christian focus on differences between true God and other beings. It would have been the primitive thought of the ancient Indians that made "obsolete the God who directs fate of the world", according to Schayer (Schayer 1925, p. 29).

The third stage brought another change in the structure of the ideas characteristic of attempts to describe the beliefs of mantra practitioners. Ideas about supernatural powers or beings as agents in magical practices were retained, but in a very vague form which allowed for fundamental changes and different additions. What was clearly respectful and adoring prayer to gods for H.T. Colebrooke, H.H. Wilson, and F.M. Müller, became 'sympathetic magic' which manipulated the same gods and brought them under the control of a Brahmin priest (see the first part of this article). Some scholars kept thinking about 'Tantric revelation' in direct response to changing ideas about God (Guenther 1968). Other attempts used the ideas about the alleged primitive thinking, which should postulate the 'hidden connections' between phenomena in this world, and called it "sacred magic" (see Gonda 1963b, pp. 28-34). This stage of research is puzzling; although some of the main ideas from the previous theorizing are retained, they are freely mixed with different other concepts. Mantras could be understood as symbols and correspondences of all kinds are imagined:

A mantra is a 'symbol' in the archaic sense of the term-it is simultaneously the symbolized 'reality' and the symbolizing 'sign'. There is an occult correspondence between the mantra's mystical letters and syllables ( ... ) and the subtle organs of human body on the one hand, and, on the other, between those organs and the divine forces asleep or manifested in the cosmos. By working on the 'symbol', one awakens all the forces that correspond to it, on all levels of being. Between the mantrayana and tantric iconography, for example, there is perfect correspondence; for each plane and each degree of sanctity has its corresponding image, color, and letter. By meditating on the color or the mystical sound that represents it, the disciple enters into a particular modality of being, absorbs or incorporate a yogic state, a god, etc. (Eliade 1958, pp. 215-16)

For other scholars, gods (or demons) did not matter anymore, because the main focus of mantras should be 'hidden connections', typically characterized as 'homologies'. Moreover, others speculated about the 'divine power' that mantras contain, and how they are identical with gods or their energy in the traditional Indian understanding (see Beck 1995, especially pp. 121-219). Yet what is firmly anchored in all these attempts is the conviction about the belief system, or worldview, that the mantra practitioners allegedly held. The originally central concept of Christian God and the difference between God and fallen angels was still present in the form of a search for believers' ideas about 'supernatural

12 Compare Schayer's ideas with the explanation of magic and the use of mantras in the chapter 'Die Religion der Primitiven' of H. v. Glasenapp's book Brahma und Buddha (Glasenapp 1926, pp. 15-32), or with G. Gilmore's understanding of "the Tantric doctrine of God" and its connection to mantras (Gilmore 1919). On discussions of the 'primitive mind', its alleged patterns and how it should have been engaged in magical thinking, it is interesting to consult other half-forgotten texts (for example Clemen 1921; Ellwood 1927; or Goode 1955). 
power'. Because the concept was not clear any more, the general idea of 'supernatural beings' soon allowed for adding ideas about 'hidden correspondences' or 'homological connections'. At this stage, a connection between humans and the supernatural could have different variants: sometimes it was a connection between humans and gods, sometimes between human body and universe ('macrocosm' and 'microcosm'), or between human mind and 'supernatural reality'. It is no wonder that coercion versus supplication does not explain anything here, because it is not clear at all who or what should be coerced. As the remnants of the originally clear-cut division between transcendental God and the demons of this world were lost, the other-worldly and this-worldly goals of Indian traditions merged together. It is not clear anymore what exactly all these concepts mean and why we are still using them.

\section{Conclusions: Before Pursuing New Routes for Understanding Mantras}

We have argued that not only individual concepts but the whole structure of ideas arising from Christian theological concerns with God and fallen angels became the core of modern theorizing about Indian mantras. Graaf's question about coercion led us to clarification of the conceptual problems with spell and prayer. Originally, both were clearcut ideas of the Christian Apologists, who argued that the Christian God was fundamentally different from the gods of the 'pagan' traditions of the late Roman empire. The latter were identified with biblical fallen angels, or their progeny. Fathers of the Early Church built a coherent explanation, where man either prays to one true God, or uses spells in order to manipulate demons. The attitudes of the believers cannot differ more in the eyes of theologians: The worship of God is expressed in adoration, thanksgiving, and humble requests posed with trust in the Almighty's wisdom and love; demons are coerced through the art of spells, which is true manipulation. Connected with these ideas are also evaluations of the goals humans can attain by these practices. Salvation of the soul is the final goal for a good Christian, with the understanding that the needs of this, worldly, life are supplied by the Creator. For both kinds of goals, human beings should humbly pray to the Creator. If humans are seduced by demons, they aim at this-worldly goals and become ensnared by riches and other pleasures (or by delusions of demons). In this structure of ideas, the difference between the concept of God and demons implies other differences: that between prayer and spell, a supplicatory attitude on the part of worshippers versus a coercive one, and differences between this-worldly and other-worldly goals. All these concepts clarify the central Christian theme, which is the nature of supernatural God and the human relationship with Him. Prayers are a means of communication between humans and God, spells between humans and demons. This structure of ideas also explains how religion and magic can be understood as different, and yet somehow also the same kind of phenomena. False religion (magic) is also religion; it was originally the proper search for a relationship with God, which was misdirected to false gods (demons). In this perspective, demons can only pretend they are in the position of the Almighty, while they are doing their magic.

When early European Orientalists and other interested authors struggled with understanding mantras in India, the structures of Christian ideas about religion as the worship of one true God were the natural and, in fact, the only available meaningful explanation for them. These ideas were also in the background of developing theories about the religious evolution of humankind for the Enlightenment thinkers (Harrison 1990) Therefore, if Indian practices were expressions of original monotheism in the eyes of respective scholars, mantras were understood to be prayers. If the growing body of scholarship decided that Indians practiced idolatry, mantras became spells. Ideas about evolution and degeneration of religion could stand next to each other; in all cases, magical practices were identified with the help of criteria established by the Early Church Fathers. Thus, the alleged Vedic monotheism led H.T. Colebrooke, H.H. Wilson, F.M. Müller, and others to describe mantras from Rg, Sama, and Yajur Veda Samhitas as prayers. The Atharva Veda Samhita soon became 'the classical example' of the degeneration of religion from monotheism to the 
'ocean of sorcery'; hence, its mantras were described as spells. The same criteria were applied to Puranic, Tantric, and other mantras. At this stage, the explanation remained coherent and meaningful, because the central ideas about God and demons were basically retained.

It is important to see how the originally coherent structure of ideas was loosened and finally dissolved, resulting in the rejection of explicitly Christian ideas about transcendental God and demons of this world. Yet the process was slow, as Schayer's arguments show. The focus on the nature of a biblical God and demons remains with us, transformed into questions about the beliefs of the mantra practitioners in 'supernatural powers'. The alleged beliefs are still the main focus of research, and the results of scholarly efforts to understand them also determine whether mantras are characterized as spells or prayers. However, this shift caused changes properly described as a conceptual mess. Firstly, the concepts became vague and the relationship between them is not clear, which allows for explanations that would be mutually exclusive in the original understanding. The description of mantras from Rg Veda is a good example: what was clearly prayer for the early Orientalists, adoring and humbly petitioning Vedic gods, became manipulation of the same gods in later scholarly works. Secondly, the relationship with God or demons can be replaced by other relationships in the alleged worldview of mantra practitioners: either it is between men and gods (or demons; the demarcation here is dubious), or humans believe in the manipulation of 'hidden' connections in the universe, or it is a relation between the human body and the universe, or even between the human mind and divine (or 'cosmic') sound. Thirdly, the character of the coercive versus supplicatory approaches of the worshippers became a problem in itself. When you remove the ideas about a biblical God and demons, it is no longer clear to whom or to what a worshipper is submissive, and what exactly such submission means. Why should prayer be characterized by these concepts? Their vagueness allows for arbitrary decisions and even for 'merging' them. The same is true for the use of differences between human goals as characteristic of prayers or spells. What is their relationship with all the different ideas about 'supernatural powers' that mantra practitioners allegedly hold? Fourthly, the original meaning of magical and religious practices' being different and yet of the same kind plays a role of vague intuition in the background of academic discussions. This is why some scholars can retain the dividing characterization, however problematic it becomes; others reject it; and yet others keep the division in even more obscure talk about scales, overlapping of categories, and mantras' being magico-religious practices.

We see how the concept of belief plays an important role in the debates. In a way, this concept was also the uncontested conviction about the presence of a set of ideas similar to the Christian concepts in the minds of mantra-practitioners. Several generations of scholars almost automatically assumed that there must be a magical belief, or magical worldview, which is the ground for magical practices. This conviction was also part of a larger project in developing an evolutionary theory of human thought, and even though most scholars today do not accept the theories of Tylor, Mauss, or Frazer, the search for the specific content of a magical worldview did not stop. Yet the search results suggest that scholars are looking for something that simply need not be present in the thought of many traditions of mantrapractice. Let us take Tantric studies again as an example. Recognized scholars in this field wrote about fundamental problems in the efforts to reconstruct Tantric philosophy or worldview and suggested that 'there is some plausibility in the statement that metaphysical subtleties have been superimposed upon an original fund of practical yogic and mantric methods' (Gupta et al. 1979, p. 47). A. Bharati pointed out how Tantric literature is not a philosophical genre, because it focuses mainly on practices, and introduced 'psychoexperimental speculation' as its more appropriate description (Bharati 1975, pp. 15-18). Finally, we should mention the analysis of F. Staal, which shows how ritual and mantras in Asia "are transmitted without interpretation or with constantly changing interpretations, and are engaged in for their own sakes" (Staal 1996, p. 400). The Dutch scholar argued for basic meaninglessness of ritual and mantra in India, against the dominant search for 
doctrines and beliefs as the most important way of understanding these practices. In sum, the search for magical beliefs is a dubious enterprise at least, because practices were apparently much more important than ideas developed about them in diverse schools of Indian thought.

However, the loosened concepts from the originally coherent structure of Christian ideas still play a double role in theorizing mantras: as concepts of the alleged magical worldview (thus was 'Indian demonology' constructed), and as part of the conceptual apparatus of theories themselves. In the first role, these concepts should accurately describe the content of beliefs from the Indian perspective. In the second role, they should explain what it is that Indians believe. Apparently, in both roles they are failing. Indians could hardly have equivalents of Christian concepts (Piatigorski 1985, pp. 208-58). As theoretical concepts, they still depend on the assumptions about a biblical God, but they do not have even the clarity and coherence of the original Christian explanation. In this sense, their role is not comparable to the role of biblical ideas about the creation of this world for developments in early modern physics or astronomy. Moreover, if we were to accept these explanations, the very same phenomenon (a chosen mantra) would change its nature according to the beliefs of the practitioner. This is hardly an interesting direction for research, which should provide us with insights into the nature, functioning, effects, etc., of the phenomenon in question. Why are we still adopting such constraints?

Indian ideas about brahman and sound became drawn into this framework of originally Christian ideas. This is a separate topic for fresh research, which we cannot take up at the end of our inquiry here. Nevertheless, it should be noted that the alleged content of 'primitive magical beliefs' looks like a strange mixture of the Christian ideas analyzed along with concepts from different schools of Indian thought that may not have been understood properly. The power originally attributed to God, to demons, or to 'supernatural powers' is now attributed to mantras themselves. Western and Indian scholars alike talk about mantras being 'God's Creative Power incarnate in sound' (Gonda 1963a, p. 294), or 'divine sound', which enables one to describe 'sonic theology' in Hinduism (Beck 1995). Yet Indian mantras are hardly seen as divine (transcendent), or even perfect in the traditional understanding, because you can read about complex practices that Indians developed in order to purify mantras, to perfect them, and to make them work. Therefore, mantras look very much like this-worldly phenomena, 'always with some imperfections' (Bühnemann 1991). The original Christian question of agency (either God acts, or demons act) also remains; hence, mantras became the causal forces in some scholarly speculations, although F. Staal convincingly argued that this is not the traditional Indian understanding (Staal 1996, pp. 237-42).

We suggest that in-depth analyses of the problematic concepts of 'spell' and 'prayer' are necessary, because unless we understand what exactly is wrong with them, it will be difficult to pave new ways for understanding mantras. Whether it will mean testing of Staal's proposal to understand mantras as remnants of a pre-conceptual stage of development of human mind and communication (Staal 1996, pp. 253-93); critique of applications of Austin's ideas about 'speech acts' (Austin 1965; Tambiah 1968; McDermott 1975; Alper 1989); or thinking about altogether different explanations; all new attempts should include a clear understanding of the problems caused by transformations of Christian theological ideas about magic. Otherwise, we will be prone to sliding back to the conceptual problems outlined above.

Author Contributions: Conceptualization, M.F.; data collection, M.F. and P.H.; writing-original draft preparation, M.F. and P.H. Writing-review and editing, M.F. and P.H. All authors have read and agreed to the published version of the manuscript.

Funding: M.F. did not receive external funding. P.H.'s research was funded with the "Support for the Long-Term Conceptual Development of the Research Organisation RVO: 68378076, Institute of Ethnology of the Czech Academy of Sciences."

Institutional Review Board Statement: Not applicable. 
Informed Consent Statement: Not applicable.

Data Availability Statement: Not applicable.

Conflicts of Interest: The authors declare no conflict of interest.

\section{References}

Alper, Harvey P., ed. 1989. Mantra. Albany: State University of New York Press.

Alt, Peter-André, Jutta Eming, Tilo Renz, and Volkhard Wels, eds. 2015. Magia Daemoniaca, Magia Naturalis, Zouber: Schreibweisen von Magie Und Alchemie in Mittelalter Und Früher Neuzeit, 1st ed. Leipzig: Otto Harrassowitz. [CrossRef]

Athanasius. 1971. Contra Gentes and De Incarnatione. Translated by Robert W. Thomson. Oxford: Clarendon Press.

Augustine, Aurelius. 1892. On Christian Doctrine; The Enchiridion; On Catechism and On Faith and the Creed, 3rd ed. IX vols, Translated by Stewart Dingwall Fordyce Salmond, and James Fordyce Shaw. The Works of Aurelius Augustine, Bishop of Hippo. Edinburgh: T. T. Clark.

Austin, John. 1965. How to Do Things with Words. Oxford: Oxford University Press.

Avalon, Arthur. 1950. The Serpent Power. Madras: Ganesh \& Co.

Balagangadhara, S. N. 1994. 'The Heathen in His Blindness ... ' Asia, the West and the Dynamic of Religion. Leiden: Brill.

Basham, Arthur L., ed. 1996. Cultural History of India, 10th ed. Delhi: Oxford University Press.

Basham, Arthur L. 2004. The Wonder that Was India. A Survey of the History and Culture of the Indian Sub-Continent before the Coming of the Muslims, 3rd revised ed. London and Oxford: Picador.

Beck, Guy L. 1995. Sonic Theology. Hinduism and Sacred Sound. Delhi: Motilal Banarsidass.

Behringer, Wofgang. 2004. Witches and Witch-Hunts. Cambridge: Polity Press.

Bharati, Agehananda. 1975. The Tantric Tradition, 3rd revised ed. New York: Samuel Weiser, Inc.

Bogdan, Henrik. 2012. Introduction: Modern Western Magic. Aries 12: 1-16. [CrossRef]

Boublík, Vladimír. 2000. Teologie Mimokřest'anských Náboženství. Czech translation of Boublík's original Teologia delle religioni, Roma 1973. Kostelní Vydří: Karmelitánské nakladatelství a Academia Cristiana (Roma).

Bradnick, David L. 2017. Evil, Spirits and Possession: An Emergentist Theology of the Demonic. 25 vols, Global Pentecostal and Charismatic Studies. Leiden and Boston: Brill.

Bronkhorst, Johannes. 2001. Etymology and Magic: Yaska's Nirukta, Plato's Cratylus, and the Riddle of Semantic Etymologies. Numen 48: 147-203. [CrossRef]

Bühnemann, Gudrun. 1991. Selecting and Perfecting Mantras in Hindu Tantrism. Bulletin of the School of Oriental and African Studies, University of London 54: 292-306. [CrossRef]

Burchett, Patton E. 2008. The 'Magical' Language of Mantra. Journal of the American Academy of Religion 76: 807-43. [CrossRef] [PubMed]

Butler, Alison. 2011. Victorian Occultism and the Making of Modern Magic: Invoking Tradition. Palgrave Historical Studies in Witchcraft and Magic. Basingstoke and New York: Palgrave Macmillan.

Cavendish, Richard. 1987. A History of Magic. London: Weidenfeld \& Nicolson.

Charpentier, Jarl. 1932. Brahman. Eine Sprachwissenschaftlich-Exegetisch-Religionsgeschichtliche Untersuchung. Uppsala: Almqvist \& Wiksells.

Clemen, Carl. 1921. Wesen und Urpsrung der Magie. Archiv für Religionspsychologie/Archive for the Psychology of Religion 2-3: 108-35. [CrossRef]

Cohen, Signe. 2020. Memory, Desire, and 'Magic': Smara in the Atharvaveda. Religions 11: 434. [CrossRef]

Colebrooke, Henry Thomas. 1858. Essays on the Religion and Philosophy of the Hindus, New ed. London and Edinburgh: Williams and Norgate.

Collins, Derek. 2008. Magic in the Ancient Greek World. Blackwell Ancient Religions. Malden: Blackwell Pub.

Conze, Edward. 1953. Buddhism: Its Essence and Development. Oxford: Bruno Cassirer.

de Silva Goonaratne, Dandris. 1865. On Demonology and Witchcraft in Ceylon. Journal of the Ceylon Branch of the Royal Asiatic Society 4: 1-117.

Deussen, Paul. 1894. Allgemeine Geschichte der Philosophie mit Besonderer Berücksichtung der Religionen, Erster Band. Leipzig: F. A. Brockhaus.

Douglas, James Dixon, and Merrill Chapin Tenney, eds. 1987. The New International Dictionary of the Bible. Grand Rapids: Zondervan Publishing House, Basingstoke: Marshall Pickering.

Dubois, Jean. 1906. Hindu Manners, Customs and Ceremonies, 3rd English ed. Oxford: Clarendon Press.

Eliade, Mircea. 1958. Yoga: Immortality and Freedom. New York: Pantheon Books.

Eliade, Mircea, and Charles J. Adams. 1987. The Encyclopedia of Religion. New York: MacMillan.

Ellwood, Charles A. 1927. Primitive Concepts and the Origin of Cultural Patterns. American Journal of Sociology 33: 1-13. [CrossRef]

Evans-Pritchard, Edward E. 1965. Theories of Primitive Religion. Oxford: Clarendon Press.

Ewing, Arthur H. 1902. The Carada-tilaka Tantra. Journal of the American Oriental Society 23: 65-76. [CrossRef]

Flood, Gavin. 1998. An Introduction to Hinduism. New Delhi: Oxford University Press.

Frazer, James George. 1922. The Golden Bough: A Study in Magic and Religion. London: Palgrave Macmillan UK. [CrossRef]

Gager, John G., ed. 1992. Curse Tablets and Binding Spells from the Ancient World. New York and Oxford: Oxford University Press. 
Gilmore, George W. 1919. Tantrism: The Newest Hinduism. The American Journal of Theology 23: 440-57. [CrossRef]

Glasenapp, Helmut von. 1926. Brahma und Buddha. Die Religionen Indiens in ihrer geschichtlichen Entwicklung. Berlin: Deutsche Buch-Gemeinschaft.

Gonda, Jan. 1950. Notes on Brahman. Utrecht: J. L. Beyers.

Gonda, Jan. 1963a. The Indian Mantra. Oriens 16: 244-97. [CrossRef]

Gonda, Jan. 1963b. Die Religionen Indiens II. Der jüngere Hinduismus. Stuttgart: W. Kohlhammer Verlag.

Goode, William J. 1955. Contemporary Thinking about Primitive Religion. Sociologus, Neue Folge/New Series 5: 122-32.

Goudriaan, Teun. 1978. Maya Divine and Human: A Study of Magic and Its Religious Foundation in Sanskrit Texts. Delhi: Motilal Banarsidass.

Graf, Fritz. 1997. Magic in the Ancient World. Revealing Antiquity 10. Cambridge: Harvard University Press.

Granholm, Kennet. 2014. Dark Enlightenment: The Historical, Sociological, and Discursive Contexts of Contemporary Esoteric Magic. 18 vols, Aries Book Series; Texts and Studies in Western Esotericism. Leiden and Boston: Brill.

Guenther, Herbert V. 1968. Tantra and Revelation. History of Religions 7: 279-301. [CrossRef]

Gupta, Sanjukta, Dirk Jan Hoens, and Teun Goudriaan, eds. 1979. Hindu Tantrism. Leiden: E. J. Brill.

Harrison, Peter. 1990. 'Religion' and the Religions in the English Enlightenment. Cambridge: Cambridge University Press.

Harvey, Peter. 1990. An Introduction to Buddhism: Teaching, History and Practices. Cambridge: Cambridge University Press.

Hastings, James, ed. 1910. Encyclopaedia of Religion and Ethics. Vol. III. Burial-Confessions. New York: Charles Scribner's Sons, Edinburgh: T. \& T. Clark.

Heiler, Friedrich. 1979. Erscheinungsformen und Wesen der Religion. 2e überarbeitete Auflage. Stuttgart: W. Kohlhammer Verlag.

Hildburgh, Walter Leo. 1908. Notes on Sinhalese Magic. The Journal of the Royal Anthropological Institute of Great Britain and Ireland 38: 148-206. [CrossRef]

Hippolytus. 1868. The Refutation of All Heresies with Fragments from His Commentaries on Various Books of Scripture. vol. I, Translated by Stewart Dingwall Fordyce Salmond. Ante-Nicene Christian Library: Translations of the Writings of the Fathers. Salmond. Edinburgh: T. T. Clark.

Hooykaas, Reijer. 1972. Religion and the Rise of Modern Science. Edinburgh and London: Scottish Academic Press.

Jamison, Stephanie W. 1991. The Ravenous Hyenas and the Wounded Sun. Myth and Ritual in Ancient India. Ithaca and London: Cornell University Press.

Jevons, Frank B. 1896. An Introduction to the History of Religion. London, Meuthen and New York: Macmillan.

Johnston, Sarah Illes. 2003. Describing the Undefinable: New Books on Magic and Old Problems of Definition. History of Religions 43: $50-54$.

Justin Martyr, and Athenagoras. 1909. The Writings of Justin Martyr and Athenagoras. II vols, Translated by Marcus Dods, George Reith, and Benjamin Plummer Pratten. The Ante-Nicene Christian Library: Translations of the Writings of the Fathers down to A. D. 325. Edinburgh: T. T. Clark.

Justin Martyr, and Irenaeus. 1913. The Apostolic Fathers: Justin Martyr and Irenaeus. vol. I, Edited by Cleveland Coxe. The Ante-Nicene Fathers: Translations of the Writings of the Fathers down to A. D. 325. New York: Charles Scribner's Sons.

Keppens, Marianne, and Jakob De Roover. 2020. The Brahmin, the Aryan, and the Powers of the Priestly Class: Puzzles in the Study of Indian Religion. Religions 11: 181. [CrossRef]

Klutz, Todd, ed. 2003. Magic in the Biblical World: From the Rod of Aaron to the Ring of Solomon. Journal for the Study of the New Testament 245. London and New York: T \& T Clark International.

Lactantius. 1871. The Works of Lactantius. vol. I, Translated by William Fletcher. Ante-Nicene Christian Library. Edinburgh: T. \& T. Clark.

Lake, Kirsopp. 1917. The Apostolic Fathers, with an English Translation in Two Volumes: The Shepherd of Hermas, The Martyrdom of Polycarp, The Epistle to Diognetus. II vols, LCL 25. London: William Heinemann, New York: G. P. Putnam's Sons.

Levack, Brian P. 2013. The Devil Within: Possession and Exorcism in the Christian West. New Haven: Yale University Press.

Lévy-Bruhl, Lucien. 1926. How Natives Think. London: George Allen and Unwin Ltd.

Lloyd, Geoffrey E. R. 1979. Magic, Reason and Experience: Studies in the Origin and Development of Greek Science. Cambridge: Cambridge University Press.

Luhrmann, Tanya. 1989. Persuasions of the Witch's Craft: Ritual Magic in Contemporary England. Cambridge: Harvard University Press. Lyall, Alfred C. 1899. Asiatic Studies: Religous and Social. Second Series; London: Murray.

Malinowski, Bronislaw. 1935. Coral Gardens and Their Magic: The Language of Magic and Gardening, 2nd ed. II vols, London: George Allen and Unwin Ltd.

Martin, Dale B. 2010. When Did Angels Become Demons? Journal of Biblical Literature 129: 657-77. [CrossRef]

Mauss, Marcel. 2001. A General Theory of Magic. Translated by Robert Brain. Routledge Classics. London and New York: Routledge. First published 1902.

McDermott, A. C. S. 1975. Towards Pragmatics of Mantra Recitation. Journal of Indian Philosophy 3: 283-98. [CrossRef]

Meggitt, Justin J. 2013. Did Magic Matter? The Saliency of Magic in the Early Roman Empire. Journal of Ancient History 1: 170-229. [CrossRef]

Michaels, Axel. 2004. Hinduism: Past and Present. Translated by Barbara Harshav. Princeton and Oxford: Princeton University Press. 
Monier-Williams, Monier. 1883. Religious Thought and Life in India. An Account of the Religions of the Indian Peoples, Based on a Life's Study of Their Literature and on Personal Investigations in Their Own Country. Part I. London: John Murray.

Müller, Friedrich Max. 1869. Rig-Veda-Sanhita. The Sacred Hymns of the Brahmans. vol. I, London: Trübner and Co.

Origen, and Henry Chadwick. 1980. Contra Celsum, 3rd ed. Cambridge and New York: Cambridge University Press.

Otto, Bernd-Christian. 2011. Magie: Rezeptions-Und Diskursgeschichtliche Analysen von Der Antike Bis Zur Neuzeit. Religionsgeschichtliche Versuche und Vorarbeiten, Bd. 5. Berlin and New York: De Gruyter.

Otto, Bernd-Christian. 2013. Towards Historicizing 'Magic' in Antiquity. Numen 60: 308-47. [CrossRef]

Padoux, André. 1989. Mantras-What Are They? In Mantra. Edited by Harvey P. Alper. Albany: State University of New York Press, pp. 295-318.

Pettersson, Olof. 1957. Magic-Religion: Some Marginal Notes to an Old Problem. Ethnos 22: 109-19. [CrossRef]

Piatigorski, A. 1985. Some Phenomenological Observations on the Study of Indian Religion. In Indian Religion. Edited by R. Burghart and A. Cantlie. London: Curson Press, pp. 208-58.

Radcliffe-Brown, Alfred R. 1952. Structure and Function in Primitive Society. London: Cohen \& West.

Reed, Annette Yoshiko. 2005. Fallen Angels and the History of Judaism and Christianity: The Reception of Enochic Literature. Cambridge and New York: Cambridge University Press.

Saar, Ortal-Paz. 2017. Jewish Love Magic: From Late Antiquity to the Middle Ages. Leiden and Boston: Brill.

Schayer, Stanislav. 1925. Die Struktur der magischen Weltanschauung nach dem Atharva-Veda und den Brahmana-Texten (Sonderdruck aus der "Zeitschrift für Buddhismus"). München and Neubiberg: Oskar Schloss Verlag.

Skorupski, John. 1976. Symbol and Theory: A Philosophical Study of Theories of Religion in Social Anthropology. Cambridge and New York: Cambridge University Press.

Smith, Brian K. 1989. Reflections on Resemblance, Ritual and Religion. New York: Oxford University Press.

Smith, Morton. 1996. Studies in the Cult of Yahweh. 2 vols, Edited by Shaye J. D. Cohen. Religions in the Graeco-Roman World. Leiden and New York: E.J. Brill.

Staal, Frits. 1996. Ritual and Mantras: Rules without Meaning. Delhi: Motilal Banarsidass Publishers.

Stein, Rebecca L., and Philip L. Stein. 2011. The Anthropology of Religion, Magic, and Witchcraft, 3rd ed. Upper Saddle River: Pearson Prentice Hall.

Strube, Julian. 2016. Sozialismus, Katholizismus und Okkultismus im Frankreich des 19. Jahrhunderts: Die Genealogie der Schriften von Eliphas Lévi. Religionsgeschichtliche Versuche und Vorarbeiten, Band 69. Berlin and Boston: De Gruyter.

Tambiah, Stanley Jeyaraja. 1968. The Magical Power of Words. Man 3: 175. [CrossRef]

Tambiah, Stanley Jeyaraja. 1990. Magic, Science, Religion, and the Scope of Rationality. The Lewis Henry Morgan Lectures 1984. Cambridge and New York: Cambridge University Press.

Tatian, and Theophilus. 1871. The Writings of Tatian and Theophilus; and the Clementine Recognitions. III vols, Translated by Marcus Dods, Thomas Smith, and B. P. Pratten. The Ante-Nicene Fathers: Translations of the Writings of the Fathers down to A. D. 325. Edinburgh: T. T. Clark.

Teijeiro, Manuel Garcia. 1993. Religion and Magic. Kernos. Revue Internationale et Pluridisciplinaire de Religion Grecque Antique 6: 123-38.

Tertullianus, Quintus Septimius Florens. 1869. The Writings of Tertuallian. vol. I, Translated by Sydney Thelwall, and Peter Holmes. Ante-Nicene Christian Library: Translations of the Writings of the Fathers. Edinburgh: T. T. Clark.

Tertullianus, Quintus Septimius Florens. 1903. Latin Christianity: Its Founder, Tertullian. I Apologetic; II. Anti-Marcion; III. Ethical. III vols, Edited by Cleveland Coxe. American reprint of the Edinburgh edition. The Ante-Nicene Fathers: Translations of the Writings of the Fathers down to A. D. 325. New York: Charles Scribner's Sons.

Tertullianus, Quintus Septimius Florens. 1987. De Idololatria: Critical Text, Translation and Commentary. Translated by Jan Hendrik Waszink, J. C. M. van Winden, and P. G. van der Nat. Supplements to Vigiliae Christianae, v. 1. Leiden and New York: E.J. Brill.

Tertullianus, Quintus Septimius Florens, and Marcus Minucius Felix. 1998. Apology. De spectaculis. Minucius Felix: Octavius. Translated by Terrot Reaveley Glover, and Gerald H. Rendall. Reprint. The Loeb classical library 250. Cambridge: Harvard Univ. Press.

Thomas, Keith V. 1971. Religion and the Decline of Magic: Studies in Popular Beliefs in Sixteenth-and Seventeenth-Century England. Penguin Religion. London: Penguin Books.

Thomas, Keith V. 1975. An Anthropology of Religion and Magic, II. The Journal of Interdisciplinary History 6: 91-109. [CrossRef]

Thorndike, Lynn. 1923. A History of Magic and Experimental Science: During the First Thirteen Centuries of Our Era. 2 vols, New York: The Macmillan Company.

Tylor, Edward B. 1871. Primitive Culture: Researches into the Development of Mythology, Philosophy, Religion, Art and Custom. vol. I, London: John Murray.

Upham, Edward. 1829. The History and Doctrine of Buddhism, Popularly Illustrated: With Notices on Kappoism, or Demon Worship, and of the Bali, or Planetary Incantations of Ceylon. London: R. Ackermann.

Versnel, Henk S. 1991. Some Reflections on the Relationship Magic-Religion. Numen 38: 177-97. [CrossRef]

Ward, William. 1822. A View of the History, Literature, and Religion of the Hindoos. Including a Minute Description of Their Manners and Customs, and Translations from Their Principal Works, in Three Volumes, 2nd ed. London: Kingsbury, Parbury, and Allen.

Wax, Murray, and Rosalie Wax. 1963. The Notion of Magic. Current Anthropology 4: 495-518. [CrossRef]

Williams, Paul, and Anthony Tribe. 2000. Buddhist Thought: A Complete Introduction to the Indian Tradition. London and New York: Routledge. 
Wilson, Horace H. 1861. Select Works. vol. I, London: Trübner \& Co.

Yelle, Robert. 2003. Explaining Mantras. Ritual, Rheoric, and the Dream of a Natural Language in Hindu Tantra. New York and London: Routledge. 